of the isozymes examined would appear to be 1 month following germination. Lack of activity at the $S d h 1, I d h 1, P g m 1, P g d 2$, Perl, and Per 2 loci coupled with the presence of additional $\mathrm{MDH}$ and $\mathrm{AAT}$ bands makes screening of seed tissue impractical. PER screening cannot be accomplished until seedlings have grown for 3 months. ADH screening should be performed using seed tissue because staining in leaf tissue was inconsistent. Although isozyme screening cannot be accomplished until the young seedling stage for most systems, this would still result in considerable savings in time and space to the geneticist when compared with screening at the adult stage.

\section{Literature Cited}

Arulsekar, S. and D.E. Parfitt. 1986. Isozyme analysis procedures for stone fruits, almond, grape, walnut, pistachio, and fig. HortScience 21:928-933.

Arulsekar, S., D.E. Parfitt, and D.E. Kester. 1986a. Comparison of isozyme variability in peach and almond cultivars. J. Hered. 77:272-274.

Arulsekar, S., D.E. Parfitt, W. Beres, and P.E. Hansche. 1986b. Genetics of malate dehydrogenase isozymes in peach. J. Hered. 77:4951.

Conkle, M. T., P.D. Hodgskiss, L.B. Nunnally, and S. C. Hunter. 1982. Starch gel electrophoresis of conifer seeds: A laboratory manual. U.S. Dept. Agr. Forest Service Gen. Tech. Rpt. PSW64.

Chaparro, J. X., R. E. Durham, G.A. Moore, and W.B. Sherman. 1987. Use of isozyme techniques to identify peach $x$ 'Nonpareil' almond hybrids. HortScience 22:300-302.

Durham, R. E., G.A. Moore, and W.B. Sherman. 1987. Isozyme banding patterns and their usefulness as genetic markers in peach. J. Amer. Soc. Hort. Sci. 112:1013-1018.

Gottlieb, L.D. 1981. Electrdphoretic evidence and plant populations. Prog. Phytochem. 7:1-47.

Gottlieb, L.D. 1982. Conservation and duplication of isozymes in plants. Science 216:373380

Hancock, A.M. and A.F. Iezzoni. 1988. Malate dehydrogenase isozyme patterns in seven Prunus species. HortScience 23:381-383.

Hauagge, R., D.E. Kestcr, and R.A. Asay. 1987. Isozyme variation among almond cultivars: I Inheritance. J. Amer. Soc. Hort. Sci. 112:687693.

Kruger, J.E. and D.E. LaBerge. 1974. Changes in peroxidase activity and peroxidase isozyme patterns of wheat during kernel growth and maturation. Cereal Chem. 51:345-354.

Kumar, S. and A.K. Goswami. 1985. Changes in peroxidase-IAA oxidase in developing peach fruit. Indian J. Plant Physiol. 28:331-336.

Mayne, R.G. and P.J. Lea. 1984. Alcohol dehydrogenase in Hordeum vulgare: Changes in isoenzyme levels under hypoxia. Plant Sci. Lett. 37:73-78.

Markert, C.L. and F. Moller. 1959. Multiple forms of enzymes: Tissue, ontogenetic, and species specific patterns. Biochem. 45:753-763.

Messeguer, K., P. Arus, and M. Carrera. 1987. Identification of peach cultivars with pollen isozymes. Scientia. Hort. 31:107-117.

Mowrey, B. D., D.J. Werner, and D.H. Byrne. 1990. Inheritance of isocitrate dehydrogenase, malate dehydrogenase, and shikimate dehydrogenase in peach and peach $\mathrm{x}$ almond hybrids. J. Amer. Soc. Hort. Sci. (In press.)

Mowrey, B. D., D.J. Werner, and D.H. Byrne. 1990. Isozyme survey of clones of Prunus dul- cis, P. kansuensis, P. davidiona, P. mira, $P$. persica and $P$. persica subspecies Ferganensis. Scientia Hort. (In press.)

Rajora, O.P. and L. Zsuffa. 1986. Sporophytic and gametophytic gene expression in Populus deltoides Marsh., P. nigra and P. maximowiczii Henry. Can. J. Genet. Cytol. 28:476-482.

Ramirez, H., A. Hussain, W. Rota, and W. Bushuk. 1987. Isozyme electrophoregrams of 16 enzymes in five tissues of cassava (Manihot esculenta Crantz) varieties. Euphytica 36:39-48.

Scandalios, J.G. 1964. Tissue specific isozyme variation in maize. J. Hered. 55:281-285.
Stuber, C. W., J.F. Wendel, M.M. Goodman, and J.S.C. Smith. 1987. Techniques and scoring procedures for starch gel electrophoresis of enzymes from maize(Zea mays L.). North Carolina Agr. Res. Serv. Tech. Bul. 286.

Tanksley, S. D., D. Zamir, and C.M. Rick. 1981. Evidence for extensive overlap of sporophytic and gametophytic gene expression in Lycopersicon esculentum. Science 213:453-455.

Valpuesta, V. and M.J. Bukovac. 1983. Cherry fruit development: Indoleacetic acid oxidase isoenzymes in the seed. Physiol. Plant. 58:209213.

\title{
Greenhouse Disease Screen Facilitates Breeding Resistance to Tomato Early Blight
}

\author{
Randokh G. Gardner ${ }^{1}$ \\ Department of Horticultural Science, North Carolina State University, \\ Raleigh, NC 27695-7609
}

Additional index words. Altemaria solani, Lycopersicon esculentum, Lycopersicon hirsutum, stem resistance, foliar resistance

Abstract. An $\mathbf{F}_{2}$ population segregating for tomato (Lycopersicon esculentum Mill.) early blight resistance derived from $\mathrm{C} 1943$ was screened in the greenhouse by sprayinoculating conidia of Alternaria solani (Ellis and Martin) Jones and Grout onto stems of 6-week-old seedlings. Selected $F_{3}$ lines derived from $F_{2}$ plants with resistant, intermediate, and susceptible stem lesion reactions were grown in a replicated field trial and evaluated for foliar early blight resistance. Stem lesion and foliar resistance were closely associated, making the greenhouse screen for stem lesion resistance useful in identifying plants with foliar resistance.

Screening of tomato seedlings in the greenhouse for foliar resistance to early blight generally has not been successful. When selections with a moderate level of resistance were compared with susceptible lines, symptoms were not sufficiently different in most greenhouse tests to classify plants for level of resistance (Barksdale, 1969; Nash and Gardner, 1988a; O’Leary, 1985; Walker, 1983). In other studies, $F_{1}$ and early backcrosses of resistant PI 126445 (Lycopersicon hirsutum Humb. and Bonpl.) with susceptible $L$. esculentum lines showed sufficient resistance to be distinguishable from susceptible lines in greenhouse screening for foliar resistance (Gardner, 1984). However, as additional backcrosses and selection toward $L$. esculentum type were made, the resistance

Received for publication 14 Dec. 1988. Paper no. 11915 of the Journal Series of the North Carolina Agricultural Research Service, Raleigh, NC 276957601. Research supported in part by a grant from the North Carolina Tomato Growers Assn. The cost of publishing this paper was defrayed in part by the payment of page charges. Under postal regulations, this paper therefore must be hereby marked advertisement solely to indicate this fact.

'Associate Professor, Mountain Horticultural Crops Research and Extension Center, Fletcher, NC 28732-9216. level became lower and greenhouse screening became more difficult.

Moderate levels of foliar resistance to early blight in the USDA line 71B2 (Barksdale and Stoner, 1977) and related lines (Barksdale and Stoner, 1973), in C1943 (Barksdale and Stoner, 1977), and in advanced selections from PI 126445 have been successfully screened in field plots (Barksdale, 1971; Kongpolprom, 1980; Maiero et al., 1989; Nash and Gardner, 1988a, 1988b; O'Leary, 1985; Shoemaker and Gardner, 1986; Walker, 1983). Replication and progeny testing have, however, been necessary in North Carolina to clearly distinguish and select for resistance in crosses with susceptible lines.

Andrus et al. (1942) identified a high level of resistance to the collar rot (basal stem lesion) phase of early blight in several tomato cultivars and selections and developed a greenhouse method of screening for resistance. They indicated that collar rot resistance was correlated with foliar resistance and suggested that selection for collar rot resistance should facilitate breeding for foliar resistance.

C1943, a tomato selection with a high level of stem lesion resistance and moderate foliar resistance to early blight (Barksdale and Stoner, 1977), has been used extensively in early blight resistance breeding in North 


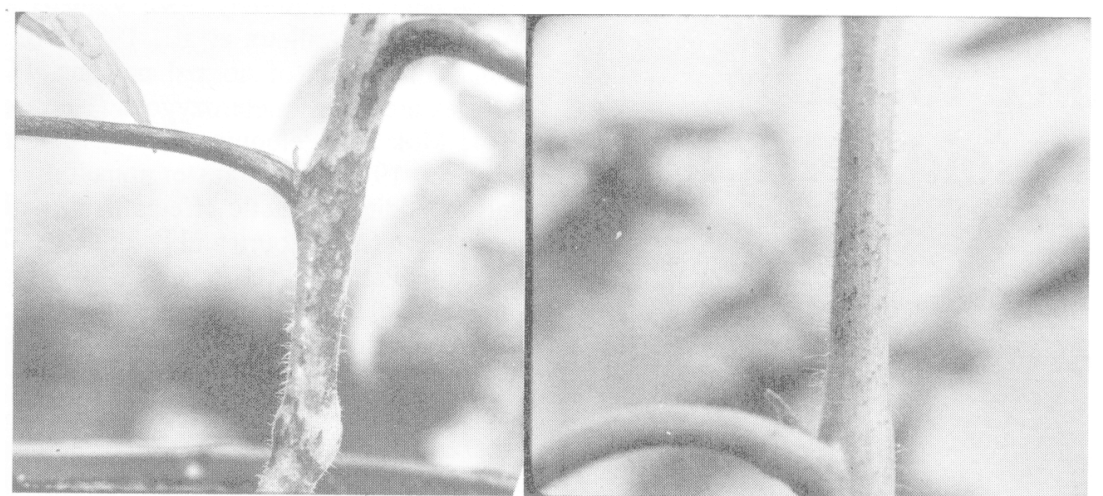

Fig. 1. Susceptiblc (left) and resistant (right) stem lesion reactions to tomato early blight.

Carolina. The breeding line NC EBR-2, derived from $\mathrm{C} 1943$ and with resistance comparable to C1943, was recently released (Gardner, 1988).

The pedigree system of breeding was used to select early blight resistance from C1943. Resistance was selected in field plots by using a reduced fungicide schedule and artificial inoculation, when needed, to induce early blight development. Advanced inbred lines selected from replicated field plots have been screened in the greenhouse for stem lesion resistance by spray-inoculating the stems of 5-to 6-week-old seedlings. Lines exhibiting foliar resistance in the field have consistently shown stem lesion resistance comparable to C1943 in greenhouse inoculations.

In 1987, a study was made to evaluate foliar resistance in the field of selected $\mathrm{F}_{3}$ lines derived from an $\mathrm{F}_{2}$ population that was tested for stem lesion resistance in the greenhouse. The $\mathrm{F}_{2}$ population, NC 86266(X), was tested in the greenhouse in Jan. 1987 for stem lesion resistance. This population was derived from the cross of NC 22E-1(85), an advanced early blight-resistant selection derived from C1943, and NC 15-1W(85), an early maturing, early blight-susceptible line.

Ninety-six, 6-week-old plants grown in 0.9liter plastic pots containing a peat-vermiculite medium were inoculated by atomizing a suspension of conidia of $A$. solani $(\approx 10,000$ spores $/ \mathrm{ml})$ onto the basal area of the stem. Inoculum was produced by the procedures described by Barksdale (1969). Six plants each of NC 22E-1 (85) and NC $15-1 \mathrm{~W}(85)$ were also inoculated. Following inoculation, plants were placed in a plasticcovered chamber, watered with a mist nozzle in late afternoon before closing the chamber and were continuously misted by operating a cool-mist humidifier for $15 \mathrm{hr}$. The chamber was opened each morning and plants were allowed to dry during the day. The greenhouse was maintained at $17 \mathrm{C}$ during the night and 21 to $29 \mathrm{C}$ during the day.

Plants were rated for stem lesion development 1 week after inoculation. Plants were classified as resistant if they developed small necrotic fleck lesions similar to the resistant parent and susceptible if they developed large lesions similar to the susceptible parent (Fig. $1)$. Of the 96 inoculated $F_{2}$ plants, seven were classified as resistant as NC 22E-1(85),
44 were classified as suscpetible as NC 15$1 \mathrm{~W}(85)$, and 45 were classified as intermediate in lesion type to the parents. The seven resistant plants, 12 plants with intermediate resistance, and six susceptible plants were transplanted to larger pots and self-pollinated.

Plants of $22 \mathrm{~F}_{3}$ families (derived from six resistant, 11 intermediate, and five susceptible $\mathrm{F}_{2}$ plants) and the parents were grown in a randomized complete-block design in a field plot at the Mountain Horticultural Crops Research Station, Fletcher, N.C. in Summer 1987. Four, six-plant plots of each line were grown on short stakes using the Florida stringweave system of culture. Fungicides for early blight were applied every 10 days instead of the 5-day schedule normally used in this area. Ratings for early blight defoliation were made 87 days after planting by estimating the percentage defoliation of each six-plant plot.

Of six $\mathrm{F}_{3}$ families derived from $\mathrm{F}$, plants resistant to stem lesions in the greenhouse, five were as resistant as NC 22E-1(85) and one was susceptible to foliar early blight in the field. Of 11 families derived from $F_{2}$ selections rated intermediate in stem lesion development compared to the parents in the greenhouse, three families were resistant, two were susceptible, and six segregated for foliar resistance in the field. Of five families derived from $\mathrm{F}_{2}$ selections susceptible to stem lesion development in the greenhouse, four were susceptible to foliar blight in the field and one segregated for resistance.

As a follow-up to the field study, greenhouse inoculations were made in Fall 1987 on seedlings of $32 \mathrm{~F}_{4}$ families derived from $\mathrm{F}_{3}$ individuals selected for foliar resistance in the field plots. All $\mathrm{F}_{4}$ families showed a high level of stem lesion resistance similar to NC 22E-1(85), except one line, which was rated susceptible. This selection came from an $\mathrm{F}_{3}$ family that segregated for foliar resistance. The other 31 selections came from $F_{3}$ families that appeared homozygous for resistance in the field.

The conclusion from the above comparison of greenhouse screening for stem lesion resistance with field screening for foliar resistance to early blight is that resistance to these two phases of the disease, derived from C1943, is closely associated. This result indicates that foliar resistance and stem lesion resistance derived from $\mathrm{C} 1943$ are controlled by the same or very closely linked genes. The ability to screen for stem lesion resistance in the greenhouse greatly facilitates the incorporation of the C1943 source of early blight resistance into improved germplasm. Greenhouse screening would also enable breeders in areas where field screening for early blight resistance is ineffective to incorporate this resistance source. Breeders are, however, cautioned to use progeny testing to verify resistance in selected individuals.

The approach discussed here may not be suitable for other sources of early blight resistance. Barksdale and Stoner (1973) reported that genes for stem lesion and foliar resistance segregated independently in segregating populations derived from the USDA early blight-resistant breeding lines 67B833 and 68 B134. NC EBR-1, a source of early blight resistance derived from PI 126445 (Gardner, 1988), has foliar resistance, but is susceptible to the stem lesion phase of early blight, making it unsuitable for the breeding approach used with the C1943 resistance source.

\section{Literature Cited}

Andrus, C. F., G.B. Reynard, H. Jorgensen, and J. Eades. 1942. Collar rot resistance in tomatoes. J. Agr. Res. 65:339-346.

Barksdale, T.H. 1969. Resistance of tomato seedlings to early blight. Phytopathology 59:443446.

Barksdale, T.H. 1971. Field evaluation for tomato early blight resistance. Plant Dis. Rptr. 55:807809.

Barksdale, T.H. and A.K. Stoner. 1973. Segregation for horizontal resistance to tomato early blight. Plant Dis. Rptr. 57:964-965.

Barksdale, T.H. and A.K. Stoner. 1977. A study of the inheritance of tomato early blight resistance. Plant Dis. Rptr. 61:63-65.

Gardner, R.G. 1984. Use of Lycopersicon hirsutum P.I. 126445 in breeding early blight-resistant tomatoes. HortScience 19:208. (Abstr.)

Gardner, R.G. 1988. NC EBR-1 and NC EBR-2 early blight resistant tomato breeding lines. HortScience 23:779-781.

Kongpolprom, W. 1980. Inheritance of resistance to early blight caused by Alternaria solani (Ell. and G. Mart) Ser. in tomato (Lycopersicon esculentum Mil.). PhD Diss., North Carolina State Univ., Raleigh.

Maiero, M., T.J Ng, and T.H. Barksdale. 1989. Combining ability estimates for early blight resistance in tomato. J. Amer. Soc. Hort. Sci. 114:118-121.

Nash, A.F. and R.G. Gardner. 1988a. Tomato early blight resistance in a breeding line derived from Lycopersicon hirsutum P.I. 126445. Plant Dis. 72:206-209.

Nash, A.F. and R.G. Gardner. 1988b. Heritability of tomato early blight resistance derived from Lycopersicon hirsutum P.I. 126445. J. Amer. Soc. Hort. Sci. 113:264-268.

O'Leary, D.J. 1985. Effects of fungicides and resistance on epidemics of tomato early blight. PhD Diss., North Carolina State Univ., Raleigh.

Shoemaker, P.B. and R.G. Gardner. 1986. Resistance and fungicide application interval for tomato foliar diseases, 1985. Biol. Cult. Tests $1: 24$

Walker, A.R. 1983. Evaluation of selected tomato breeding lines for early blight resistance. MS Thesis, North Carolina State Univ., Raleigh. 